\title{
Sensitivity and specificity of increased pulse pressure as a diagnostic test for K/DOQI stage IIII-b CKD
}

\author{
Ana I. Pérez-Castañeda, ${ }^{1}$ Gilberto F. Vázquez-de Anda, ${ }^{1 *}$ Patricia Cerecero-Aguirre, ${ }^{1}$ \\ Rodolfo Rivas-Ruíz, ${ }^{2}$ María G. Delaye-Aguilar ${ }^{1}$ and Juan O. Talavera ${ }^{2}$ \\ ${ }^{1}$ Multidisciplinary Health Clinic, Universidad Autónoma del Estado de México, State of Mexico; ${ }^{2}$ Clinical Research Training Center, Centro Médico \\ Nacional Siglo XXI, Instituto Mexicano del Seguro Social, Mexico City; ${ }^{3}$ Directorate of Teaching and Research, Centro Médico ABC, Mexico City. \\ Mexico
}

\begin{abstract}
Background: Increased pulse pressure (IPP) is associated with an estimated glomerular filtration $\leq 60 / \mathrm{mL} / \mathrm{min} / 1.73 \mathrm{~m}^{2}$; thus, it can be useful as a diagnostic test to identify people with K/DOQI stage III-b chronic kidney disease (CKD). Objective: To determine the usefulness of IPP as a diagnostic test for K/DOQI stage III-b CKD. Method: Diagnostic test study that included adult patients without comorbidities, registered in the Health Workers Cohort. The CKD-EPI formula was used to calculate glomerular filtration. Pulse pressure was determined by subtracting diastolic from systolic blood pressure. Sensitivity, specificity, positive predictive value, negative predictive value and prevalence were calculated using standard formulas. A ROC curve was generated to determine the area under the curve. Results: $A$ total of 6,215 patients were included. An IPP $\geq 50 \mathrm{mmHg}$ was observed to have a sensitivity of $74 \%$, specificity of $70 \%$, positive predictive value of $1 \%$, negative predictive value of $100 \%$ and a prevalence of $1 \%$. The inflection point in the ROC curve to identify K/DOQI III-b CKD was 0.71. Conclusion: An IPP $\geq 50 \mathrm{mmHg}$ is useful as a diagnostic test to identify people with K/DOQI stage III-b CKD.
\end{abstract}

KEY WORDS: Pulse pressure. Diagnostic test. Glomerular filtration. K/DOQI III-b.

\section{Sensibilidad y especificidad de la presión de pulso ampliada como prueba diagnóstica de IRC estadio K/DOQI III-b}

\section{Resumen}

Introducción: La presión de pulso ampliada (PPA) se asocia a un filtrado glomerular calculado $\leq 60 / \mathrm{mL} / \mathrm{minuto} / 1.73 \mathrm{~m}{ }^{2}$, por lo que puede ser útil como prueba diagnóstica para identificar a personas con insuficiencia renal crónica (IRC) estadio K/DOQI III-b. Objetivo: Determinar la utilidad de la PPA como prueba diagnóstica de IRC estadio K/DOQI III-b. Método: Estudio de prueba diagnóstica que incluyó a pacientes adultos sin comorbilidades, registrados en la Cohorte de Trabajadores de la Salud. Se utilizó la fórmula CKD-EPI para calcular la filtración glomerular. Se determinó la presión de pulso restando la presión arterial diastólica a la presión arterial sistólica. Se calculó sensibilidad, especificidad, valor predictivo positivo, valor predictivo negativo y prevalencia. Se elaboró una curva ROC para determinar el área bajo la curva. Resultados: Se incluyeron 6215 pacientes. Se observó que una PPA $\geq 50 \mathrm{~mm} \mathrm{Hg}$ tuvo sensibilidad de $74 \%$, especificidad de $70 \%$, valor predictivo positivo de $1 \%$, valor predictivo negativo de $100 \%$ y prevalencia de $1 \%$. El punto de inflexión en la curva ROC para identificar IRC $K / D O Q I I I-b$ fue de 0.71. Conclusión: $\mathrm{La} P P A \geq 50 \mathrm{~mm} \mathrm{Hg}$ es útil como prueba diagnóstica para identificar a personas con IRC estadio K/DOQI III-b.

PALABRAS CLAVE: Presión de pulso. Prueba diagnóstica. Filtración glomerular. K/DOQI III-b.

Correspondence:

*Gilberto F. Vázquez-de Anda

E-mail: gf_vazquez@hotmail.com
Gac Med Mex. 2020;156:424-429

Contents available at PubMed

www.gacetamedicademexico.com

0016-3813/@ 2020 Academia Nacional de Medicina de México, A.C.. Published by Permanyer. This is an open access article under the CC BY-NC-ND license (http://creativecommons.org/licenses/by-nc-nd/4.0/). 


\section{Introduction}

Chronic Kidney Disease (CKD) is a condition that at advanced stages increases the risk of cardiovascular disease-related death. ${ }^{1-3}$ If detected at early stages, timely treatment can be started to preserve renal function and delay the start of replacement therapy with dialysis and/or hemodialysis, so far the only effective treatment for these patients. ${ }^{1-5}$ Some patients may spend the first stages of the disease asymptomatically, and due to limited accessibility to health services, ${ }^{1,3}$ CKD is usually diagnosed at advanced stages, when late complications of the disease are present with replacement treatment indication, which increases the risk of death. ${ }^{1,6}$

Recent studies have identified increased pulse pressure (IPP) as a predictor of organ damage and cardiovascular risk, ${ }^{6-8}$ and it is present in patients with CKD. An IPP $\geq 45 \mathrm{mmHg}^{6}$ is associated with a decline in glomerular filtration (GF) regardless of age, gender, body mass index and presence of diabetes. ${ }^{7,8}$ However, Odaira et al. ${ }^{9}$ found no association between CKD and Doppler ultrasound pulse reflection wave, which casts doubt on the usefulness of pulse pressure as an indicator of glomerular filtration rate (GFR). ${ }^{9}$

Currently, the Kidney Disease Outcomes Quality Initiative (K/DOQI) scale, ${ }^{1}$ which is based on GFR, is used to stage CKD. GFR can be estimated (eGFR) using the Chronic Kidney Disease Epidemiology Collaboration (CKD-EPI) equation, which includes age, serum creatinine, gender and ethnicity. The scale identifies five CKD stages, with stage III-b (30 to $45 \mathrm{~mL} / \mathrm{min} / 1.73 \mathrm{~m}^{2}$ ) being associated with cardiovascular death. K/DOQI stage III-b can correspond to a target population in clinical practice to early identify patients with CKD. The association between IPP and decreased eGFR may have diagnostic value for this target population, and could early identify them in order for early treatment to be offered.

Therefore, and given the importance of developing new diagnostic screening methods that allow early identification of kidney disease, the purpose of our study was to determine the usefulness of IPP to identify patients with K/DOQI stage III-b CKD.

\section{Method}

This is a diagnostic test study.

For the selection and description of participants, the information obtained through a non-probabilistic sample selected by convenience among adult subjects without comorbidities who participated in the Mexican study of the Health Workers Cohort was reviewed. This cohort is made up of employees and relatives of workers from the Mexican Institute of Social Security of the State of Morelos, the National Institute of Public Health and the Autonomous University of the State of Mexico. Prior to initiating the study, the corresponding protocol was reviewed and approved by the ethics and research committees of the participating institutions.

A total of 13,275 subjects were invited to participate in the Health Workers Cohort Study between March 2003 and April 2006. A registry was developed for the 10,192 subjects who participated. The information of 9,142 patients whose data for the performance of the study were complete was reviewed. Data from patients aged $<18$ years and with conditions that alter pulse pressure, such as diabetes, hypertension and heart disease, among others, were excluded. Finally, the data of 6,215 adult subjects without comorbidities were analyzed (Fig. 1). Biochemical and anthropometric data from 6,215 adult subjects without comorbidities included in the Health Workers Cohort database were included.

Patient weight was determined using a calibrated electronic scale (BC-533 model, Tanita); the participants were weighed barefoot and with minimum clothing. Height was measured using a conventional stadiometer (Seca) with the patient standing barefoot, shoulders down, and with the head in position to maintain the Frankfurt plane. Measurements were taken with the tape in a horizontal plane, perpendicular to the vertical scale, touching the top of the head at the moment of inspiration.

Blood pressure was measured while the participants were sitting with the arm resting on a flat surface and at the level of the heart; a sphygmomanometer with a Citizen automatic digital monitor was used. Nurses trained to carry out the blood pressure measurement procedure performed three measurements on each individual. Through concordance correlation coefficients, the reproducibility of anthropometric and clinical measurements was evaluated, with a concordance of 0.83 to 0.90 being determined.

Twenty milliliters of blood were obtained by peripheral venipuncture, asking the subjects to show up with more than 8-hour fasting prior to sample taking. Subsequently, all samples were analyzed in the same laboratory using a Selectra XL Instrument ${ }^{\circledR}$ equipment (Randox Laboratories Ltd, Antrim, UK) and in 


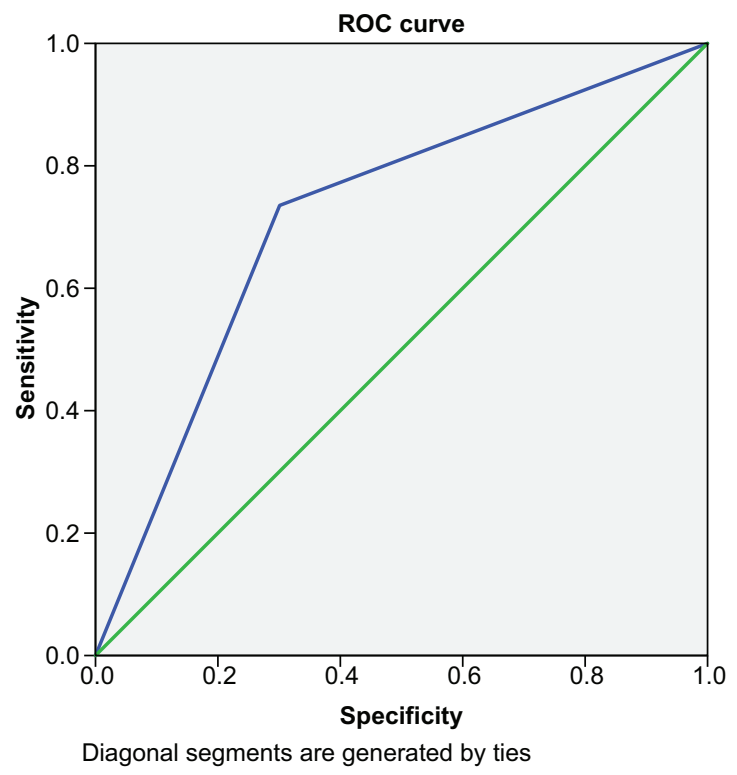

Figure 1. Criteria used for the selection of the study population sample.

accordance with the procedure established by the International Federation of Clinical Chemistry.

IPP was determined as the difference of systolic blood pressure minus diastolic blood pressure. Considering that $40 \mathrm{mmHg}$ is a pulse pressure normal parameter, an increase of at least $5 \mathrm{mmHg}$ was determined to be the criterion to define IPP. For the present study, three categories were analyzed:6-8

- An increase of 5 to $9 \mathrm{mmHg}$ ( $\geq 45$ to $\leq 49 \mathrm{mmHg}$ ).

- An increase of 10 to $14 \mathrm{mmHg}$ ( $\geq 50$ to $\leq 54 \mathrm{mmHg}$ ).

- An increase equal to or greater than $15 \mathrm{mmHg}$ ( $\geq 55 \mathrm{mmHg}$ ).

Finally, the estimated glomerular filtration rate (eGFR) was determined using the equation formulated by the Chronic Kidney Disease Epidemiology Collaboration (CKD-EPI), ${ }^{10}$ which is expressed in $\mathrm{mL} / \mathrm{min} / 1.73 \mathrm{~m}^{2}$ and is adjusted for each individual by ethnicity (white, black or other), age, gender and serum creatinine levels. Finally, glomerular filtration rate was classified according to the Kidney Disease Outcomes Quality Initiative (K/DOQI) international guidelines, with the data of patients with a glomerular filtration $\leq 60 \mathrm{~mL} / \mathrm{min} / 1.73 \mathrm{~m}^{2}$ being analyzed. . $^{2,1,12}$

The Excel program, version 2010, and the SPSS 21 statistical program, version 21, were used for statistical analysis.

$2 \times 2$ tables were generated to contrast patient eGFR and pulse pressure data. For the diagnostic test, sensitivity, specificity, positive predictive value
(PPV), negative predictive value (NPV), prevalence, diagnostic certainty and likelihood ratio of the test were determined using standard formulas. ${ }^{13-15}$

A Receiver Operating Characteristic (ROC) curve was generated to determine the optimal cutoff point for detecting GF decrease through pulse pressure

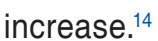

\section{Bioethical considerations}

Prior to the start of the Health Workers Cohort Study, the corresponding protocol was reviewed and approved by the ethics and research committees of the participating institutions: Mexican Institute of Social Security (12CEI 09006 14), National Institute of Public Health (13CEI 17007 36) and Autonomous University of the State of Mexico (1233008X0236). Written informed consent was obtained from all participants prior to study enrollment. Confidentiality of participants' biometric data was guaranteed through identification of each subject with a registration number and not by name.

The present study met the risk-free research criteria stipulated in article 24 of the World Medical Association Declaration of Helsinki, as well as the criterion stipulated by title two, chapter 1 , article 17 , section 1 of the General Statute of Health Regulations in Matters of Research for Health. As for ethical aspects of research on human subjects, retrospective documentary research techniques and methods were used, whereby no intentional intervention was performed (risk-free research); notwithstanding, an informed consent letter was obtained, which was signed by the participants when they joined the cohort, where they agreed to answer a questionnaire, provide blood samples, and be anthropometrically measured.

\section{Results}

Data from 6,215 adult patients without comorbidities included in the Health Workers Cohort were analyzed. Participants' mean age was $41.3 \pm 13.6$ years, systolic pressure was $115 \pm 12.9 \mathrm{mmHg}$, diastolic pressure was $70.1 \pm 10.1 \mathrm{mmHg}$, pulse pressure was $45.3 \pm 9.8$ $\mathrm{mmHg}$, serum creatinine was $0.9 \pm 0.15 \mathrm{mg} / \mathrm{dL}$, and eGFR was $85.9 \pm 20.3 \mathrm{~mL} / \mathrm{min} / 1.73 \mathrm{~m}^{2}$.

Table 1 describes data on sensitivity, specificity, positive predictive value, negative predictive value, prevalence and diagnostic certainty for patients with a glomerular filtration $\leq 60 \mathrm{~mL} / \mathrm{min} / 1.73 \mathrm{~m}^{2}$ (K/DOQI III) and IPP $\geq 45 \mathrm{mmHg}$. Table 2 shows the values of the diagnostic test calculated for IPP $\geq 45$ and an 
Table 1. Summary of statistical analyses for an IPP $\geq 45 \mathrm{mmHg}$ with GF $\leq 60 \mathrm{~mL} / \mathrm{min} / 1.73 \mathrm{~m}^{2}$ (K/DOQI stage III)

\begin{tabular}{|c|c|c|c|}
\hline & IPP $\geq 45 \mathrm{mmHg}$ & IPP $\geq 50 \mathrm{mmHg}$ & IPP $\geq 55 \mathrm{mmHg}$ \\
\hline Sensitivity (\%) & 65 & 48 & 31 \\
\hline Specificity (\%) & 50 & 71 & 85 \\
\hline Positive predictive value (\%) & 10 & 11 & 14 \\
\hline Negative predictive value (\%) & 94 & 95 & 94 \\
\hline Prevalence (\%) & 8 & 7 & 7 \\
\hline Diagnostic certainty (\%) & 52 & 69 & 82 \\
\hline Area under the curve & 0.57 & 0.59 & 0.58 \\
\hline $95 \% \mathrm{Cl}$ & $0.55-0.60$ & $0.56-0.62$ & $0.55-0.61$ \\
\hline
\end{tabular}

$\mathrm{IPP}=$ increased pulse pressure, $\mathrm{GF}=$ glomerular filtration, $\mathrm{Cl}=$ confidence interval .

Table 2. Summary of statistical analyses for an IPP $\geq 45 \mathrm{mmHg}$ with GF $\leq 45 \mathrm{~mL} / \mathrm{min} / 1.73 \mathrm{~m}^{2}$ (K/DOQI stage IIlb)

\begin{tabular}{|c|c|c|c|}
\hline & IPP $\geq 45 \mathrm{mmHg}$ & IPP $\geq 50 \mathrm{mmHg}$ & $\mathrm{IPP} \geq 55 \mathrm{mmHg}$ \\
\hline Sensitivity (\%) & 85 & 74 & 47 \\
\hline Specificity (\%) & 49 & 70 & 84 \\
\hline Positive predictive value (\%) & 1 & 1 & 2 \\
\hline Negative predictive value (\%) & 100 & 100 & 100 \\
\hline Prevalence (\%) & 1 & 1 & 1 \\
\hline Diagnostic certainty (\%) & 50 & 70 & 84 \\
\hline Area under the curve & 0.67 & 0.71 & 0.65 \\
\hline $95 \% \mathrm{Cl}$ & $0.59-0.75$ & $0.63-0.80$ & $0.55-0.76$ \\
\hline
\end{tabular}

$\mathrm{IPP}=$ increased pulse pressure, $\mathrm{GF}=$ glomerular filtration, $\mathrm{Cl}=$ confidence interval .

eGFR $\leq 45 \mathrm{~mL} / \mathrm{min} / 1.73 \mathrm{~m}^{2}$, corresponding to $\mathrm{K} / \mathrm{DOQ}$ stage III-b CKD.

The area under the curve reflected in the tables and the cutoff points for the tests were determined by generating ROC curves. Figure 1 shows the discrimination line of the test according to pulse pressure cross values $\geq 50 \mathrm{mmHg}$ and eGFR $\geq 30$ and $\leq 45 \mathrm{~mL} / \mathrm{min} / 1.73 \mathrm{~m}^{2}$ (K/DOQI stage III-b).

\section{Discussion}

Our study demonstrates that a pulse pressure $\geq 50 \mathrm{mmHg}$ has an acceptable diagnostic capacity to identify patients, without associated morbidities, with CKD at K/DOQI stage III-b. According to the Mexican Institute of Social Security, CKD at advanced stages of the disease is among the first 10 causes of general mortality and represents the eighth cause of death in males at productive age and the sixth in women aged 20 to 59 years. ${ }^{3,4}$ Due to the above, it is urgent to early identify patients at risk of experiencing a decrease in glomerular filtration at stages where the disease is asymptomatic.

In our study, mean pulse pressure of the study population was observed to be $5 \mathrm{mmHg}$ above the reference values $(40 \mathrm{mmHg}$ ). According to the literature, this pulse pressure elevation is a factor for initiation and progression to $\mathrm{K} / \mathrm{DOQ}$ stage III in the long term, ${ }^{6-8}$ given that, as pulse pressure increases, the rate of kidney disease progression grows. ${ }^{11}$

Study subjects' age was not a risk factor for CKD; however, since glomerular filtration decreases by $1 \mathrm{~mL} /$ $\mathrm{min} /$ year from age 30 onwards, monitoring renal function at least once a year is recommended in adult patients. Currently, serum creatinine value or GFR calculation using standard formulas are regarded as screening tests. ${ }^{4,11}$ 
Our study shows (through the ROC curve) that the test is able to identify two-thirds of patients with IPP $\geq 50 \mathrm{mmHg}$ and a decrease in eGFR equivalent to K/DOQI stage III-b CKD. 2.6-8,10-12,14

The capability of pulse pressure to rule out a decrease in eGFR equivalent to K/DOQI stage III-b CKD (NPV) when the patient has a pulse pressure $\leq 50 \mathrm{mmHg}$ is high. ${ }^{12,13,15}$ Calculation of predictive values to determine the probability of developing kidney disease depends on the prevalence in the study population; for this reason, PPV is low because the prevalence of the disease in our population is low, whereas NPV increases. $12,13,15$

Our study determined that both prevalence and positive predictive value (PPV) were low; therefore, the test would detect K/DOQI stage III-b CKD in one out of every 100 patients using a rapid, non-invasive technique that is carried out at each visit to the doctor or health institution..$^{12,13,15}$ Given that the obtained NPV is high, the test is able to rule out the disease in a patient with suspected K/DOQI stage III-b CKD.

On the other hand, we know that $70 \%$ of the times that the test is performed in an individual the diagnosis will be correct, and that if the patient has an IPP $\geq 50 \mathrm{mmHg}$, his GF will be lower in comparison with healthy individuals; therefore, an IPP $\geq 50 \mathrm{mmHg}$ can be used as a screening diagnostic test for K/DOQI stage III-b CKD. .2-15 $^{2}$

By itself, IPP is a characteristic that is present in patients with $\mathrm{K} / \mathrm{DOQ}$ stage III-b CKD, is a predictor of organ damage and a cardiovascular risk factor. ${ }^{6,8}$ The particularity of IPP is its association with cardiovascular disease complications and death. ${ }^{16-18}$ Despite the evidence, Mari Odaira et al. ${ }^{9}$ and Colin D. Chue et al. ${ }^{19}$ claim that, although IPP can be present in patients with $\mathrm{GF}<60 / \mathrm{mL} / \mathrm{min} / 1.73 \mathrm{~m}^{2}$, in linear regression models adjusted for age, gender and some comorbidities, no association was observed between IPP and GF decline, and IPP could therefore not be used as a GF indicator. ${ }^{9,19}$ However, a PP increase $\geq 5 \mathrm{mmHg}$ above normal values ${ }^{6}$ is associated with CKD due to the decrease in eGFR. Consequently, IPP can be used as a clinical marker to identify patients with CKD according to the K/DOQI guidelines. ${ }^{1}$

Renal replacement therapy has an elevated cost that cannot be afforded by the patient in case of not having access to social security, and familial economic situation and patient quality of life are therefore severely affected when CKD occurs. ${ }^{1,3}$ Hence the importance of timely detection of GF decrease by means of new sensitive, specific, low-cost and easy-to-implement diagnostic screening tests such as IPP, given that, at advanced stages of the disease (K/DOQI stages IV-V), the probability for the patient to suffer complications secondary to the disease itself or to late replacement therapy increases. ${ }^{1,3,8}$

According to the results obtained, carrying out new studies is planned, which should include patients with comorbidities in order to determine new cutoff points, as well as the most recent data from patients of the Health Workers Cohort.

When analyzing the data, some limitations were identified: we had to exclude 2,927 individuals because the information was not complete. The main limitation of the study was that only data of people living in the States of Mexico and Morelos were included, and thus, the results cannot be generalized to the rest of the Mexican population.

Finally, our study demonstrates that patients who had an IPP $\geq 50 \mathrm{mmHg}$, had a GF $\leq 45 / \mathrm{mL} / \mathrm{min} / 1.73 \mathrm{~m}^{2}$; therefore, an IPP $\geq 50 \mathrm{mmHg}$ can be used as a timely, sensitive and specific diagnostic screening test for K/DOQI stage III-b CKD.

\section{Conclusion}

An IPP $\geq 50 \mathrm{mmHg}$ can be used as a sensitive and specific diagnostic screening test for K/DOQI stage III-b CKD early detection in adults without comorbidities.

\section{Conflict of interests}

None.

\section{Funding}

Ana Ivonne Pérez Castañeda received a grant for doctoral studies from the National Council of Science and Technology of Mexico.

\section{Ethical disclosures}

Protection of human and animal subjects. The authors declare that no experiments were performed on humans or animals for this research.

Confidentiality of data. The authors declare that they have followed the protocols of their work center on the publication of patient data.

Right to privacy and informed consent. The authors declare that no patient data appear in this article. 


\section{References}

1. Sarcona E, Díaz M. Effect of renal disease on ambulatory blood pressure monitoring. Rev Argent Cardiol. 2015;83:135-139.

2. Medeiros M, Andrade-Veneros GD, Toussaint-Martínez-de Castro G, Ortiz-Vásquez L, Hernández-Sánchez AM, Olvera N, et al. Prevalencia de enfermedad renal en niños aparentemente sanos con antecedente familiar de terapia de reemplazo renal. Bol Med Hosp Infant Mex. 2015;72:257-261.

3. Méndez-Durán A, Méndez-Bueno JF, Tapia-Yáñez T, Muñoz-Montes A, Aguilar-Sánchez L. Epidemiología de la insuficiencia renal crónica en México. Dial Transplant. 2014;35:148-156.

4. Méndez-Durán A, Pérez-Aguilar G, Ayala-Ayala F, Ruiz-Rosas RA, González-Izquierdo JJ, Dávila-Torres. Panorama epidemiológico de la insuficiencia renal crónica en el segundo nivel de atención del Instituto Mexicano del Seguro Social. Dial Transplant. 2014;35:148-156.

5. Amato D, Álvarez-Aguilar C, Castañeda-Limones R, Rodriguez E, Vila-Diaz M, Arreola F, et al. Prevalence of chronic kidney disease in an urban Mexican population. Kidney Int Suppl. 2005,97:S11-S17.

6. Peralta CA, Jacobs DR, Katz R, Ix JH, Madero M, Duprez DA, et al. Association of pulse pressure, arterial elasticity, and endothelial function with kidney function decline among adults with estimated GFR $>60 \mathrm{~mL} /$ $\mathrm{min} / 1.73 \mathrm{~m}^{2}$ : the Multi-Ethnic Study of Atherosclerosis (MESA). Am J Kidney Dis. 2012;59:41-49.

7. Safar ME, PlanteGE, Mimran A. Arterial stiffness, pulse pressure, and the kidney. Am J Hypertens. 2015;8:561-569.

8. Luño J, Gómez-Campderá FJ, García-de Vinuesa S, Goicoechea M. Factores determinantes de la presión de pulso en la enfermedad renal crónica. Nefrologia (Madr). 2004;24:29-32.

9. Odaira M, Tomiyama H, Matsumoto C, Yamada J, Yoshida M, Shiina K, et al. Association of serum cystatin $C$ with pulse wave velocity, but not pressure wave reflection, in subjects with normal renal function or mild chronic kidney disease. Am J Hypertens. 2010;23:967-973.
10. Wood AJ, Churilov L, Perera N, Thomas D, Poon A, Maclsaac RJ, Jerums G, Ekinci El. Estimating glomerular filtration rate: performance of the CKD-EPI equation over time in patients with type 2 diabetes. J Diabetes Complications. 2016;30:49-54.

11. Flores JC, Alvo M, Borja H, Morales J, Vega J, Zúñiga C, et al. Enfermedad renal crónica: clasificación, identificación, manejo y complicaciones. Rev Med. 2009;137:137-177.

12. van Stralen KJ, Stel VS, Reitsma JB, Dekker FW, Zoccali C, Jager KJ. Diagnostic methods I: sensitivity, specificity, and other measures of accuracy. Kidney Int. 2009;75:1257-1263.

13. Talavera JO, Wacher-Rodarte NH, Rivas-Ruiz R. Investigación clínica II. Estudios de proceso (prueba diagnóstica). Rev Med Inst Mex Seguro Soc. 2011;49:163-170.

14. Tripepi G, Jager KJ, Dekker FW, Zoccali C, Diagnostic methods 2: receiver operating characteristic (ROC) curves. Kidney Int. 2009;76:252-256.

15. Burgos ME, Manterola C. Cómo interpretar un artículo sobre pruebas diagnósticas. Rev Chil Cir. 2010;62:301-308.

16. Briet M, Maruani G, Collin C, Bozec E, Gauci C, Boutouyrie P, et al. Age-independent association between arterial and bone remodeling in mild-to-moderate chronic kidney disease. Nephrol Dial Transplant. 2010;25:191-197.

17. DeLoach SS, Appel LJ, Chen J, Joffe MM, Gadegbeku CA, Mohler ER, et al. Aortic pulse pressure is associated with carotid IMT in chronic kidney disease: report from chronic renal insufficiency cohort. Am J Hypertens. 2009;22:1235-1241.

18. Verbeke F, van Biesen W, Peeters P, van Bortel LM, Vanholder RC. Arterial stiffness and wave reflections in renal transplant recipients. Nephrol Dial Transplant. 2007;22:3021-3027

19. Chue CD, Edwards NC, Davis LJ, Steeds RP, Townend JN, Ferro CJ. Serum phosphate but not pulse wave velocity predicts decline in renal function in patients with early chronic kidney disease. Nephrol Dial Transplant. 2011;26:2576-2582. 